Communications in Physics, Vol. 27, No. 3 (2017), pp. 233-244

DOI:10.15625/0868-3166/27/3/9368

\title{
FABRICATION AND EVALUATION OF THE PHOTOCATALYTIC, ANTIBACTERIAL ACTIVITY OF Ag-TiO 2 THIN FILM
}

\author{
NU QUYNH TRANG TON ${ }^{1, \dagger}$, THI NGOC TU LE ${ }^{1,2}$, DANG TRAI NGUYEN ${ }^{1}$, \\ AND THI HANH THU VU ${ }^{1}$ \\ ${ }^{1}$ University of Science, Vietmam National University, Ho Chi Minh City, \\ 227 Nguyen Van Cu, Ward 4, District 5, Ho Chi Minh City, Vietnam \\ ${ }^{2}$ Dong Thap University, \\ 783 Pham Huи Lau Street, Ward 6, Cao Lanh City, Dong Thap Province, Vietnam \\ $\dagger$ E-mail: tonnuquynhtrang94@gmail.com
}

Received 30 December 2016

Accepted for publication 19 June 2017

Published 23 August 2017

\begin{abstract}
Ag}-\mathrm{TiO}_{2}$ thin film was fabricated by the DC magnetron sputtering and photo-reduction methods. Characteristics of the film such as the surface morphology, crystal structure, and chemical composition were investigated by using the scanning electron microscope (SEM), X-ray diffractometry (XRD) and $U V$-Vis spectra. The photocatalytic activity of $\mathrm{Ag}-\mathrm{TiO}_{2}$ thin film was determined by the degradation of methylene blue $(M B)$ solution under various irradiation conditions. The antibacterial property of $\mathrm{Ag}-\mathrm{TiO}_{2}$ thin film was conducted in E. coli bacteria. Results showed that the photocatalytic and antibacterial property of $\mathrm{Ag}-\mathrm{TiO}_{2}$ thin film are better than those of pure $\mathrm{TiO}_{2}$ thin film in the visible region. $\mathrm{Ag}-\mathrm{TiO}_{2}$ thin film shows a great potential application in the antibacterial and environment field.
\end{abstract}

Keywords: $\mathrm{Ag}-\mathrm{TiO}_{2}$, thin film, DC magnetron sputtering, photocatalytic, antibacterial.

Classification numbers: 81.15.Cd; 81.16.Hc; 92.20.Jt.

\section{INTRODUCTION}

$\mathrm{TiO}_{2}$ has been widely studied as an effective photocatalytic for water treatment [1], air filter [2], antibacterial [3], self-cleaning materials [4], hydrogen generation by photocatalytic water splitting [5], etc. due to its low cost, nontoxic and environmentally friendly. However, $\mathrm{TiO}_{2}$ has a wide band gap $(3.2 \mathrm{eV})$ which only can be activated by UV region (only $5 \%$ of the solar radiation); besides that, the high recombination rate of electron-hole pairs would also decrease the (C)2017 Vietnam Academy of Science and Technology 
photocatalytic ability. There are many methods to the improvement of photocatalytic property of $\mathrm{TiO}_{2}$ such as combining $\mathrm{TiO}_{2}$ with other semiconductors $(\mathrm{ZnO}, \mathrm{CdS}, \ldots)$ [6], metals $(\mathrm{Ag}, \mathrm{Pt}, \mathrm{Cu}$, $\mathrm{Fe}, \mathrm{Ce}, \ldots$ ) [7] or non-metals $(\mathrm{N}, \mathrm{C}, \ldots)$ [8]. Besides, depositing noble metals $(\mathrm{Ag}, \mathrm{Pt}, \mathrm{Au}, \ldots)$ is an effective solution for enhancing the photocatalytic ability of $\mathrm{TiO}_{2}$. Among noble-metals, $\mathrm{Ag}$ has attracted the attention of researchers because $\mathrm{Ag}$ has been found to be more effective due to it can trap the photo-generated electrons to reduce the recombination of electron-hole [9] and opens the ability to apply in the antibacterial field [10]. In addition, the Fermi energy level of noble metal is always lower than that of semiconductor photocatalysts and facilitates the photocatalytic activity in the visible light region. The charge separation and transfer of $\mathrm{Ag}$ and $\mathrm{TiO}_{2}$ are displayed in Fig. 1. When $\mathrm{TiO}_{2}$ absorbs photons of electromagnetic radiation with energy equal or greater than its band gap, an electron will jump from the valence band to the conduction band, and create electron $\left(\mathrm{e}^{-}\right)$-hole $\left(\mathrm{h}^{+}\right)$pairs. Before the photocatalytic reaction, the $\mathrm{Ag}^{+}$ion is adsorbed on the surface of $\mathrm{TiO}_{2}$, after the photocatalytic reaction the $\mathrm{Ag}^{+}$is reduced to $\mathrm{Ag}$ metal. Reactive oxygen species such as the hydroxyl radical $\left({ }^{\bullet} \mathrm{OH}\right)$, the superoxide anion radical $\left(\mathrm{O}_{2}^{-}\right)$and hydrogen peroxide $\left(\mathrm{H}_{2} \mathrm{O}_{2}\right)$ are the dominant species contributing to the degradation of various organic pollutants and breaking down bacterial cell walls.

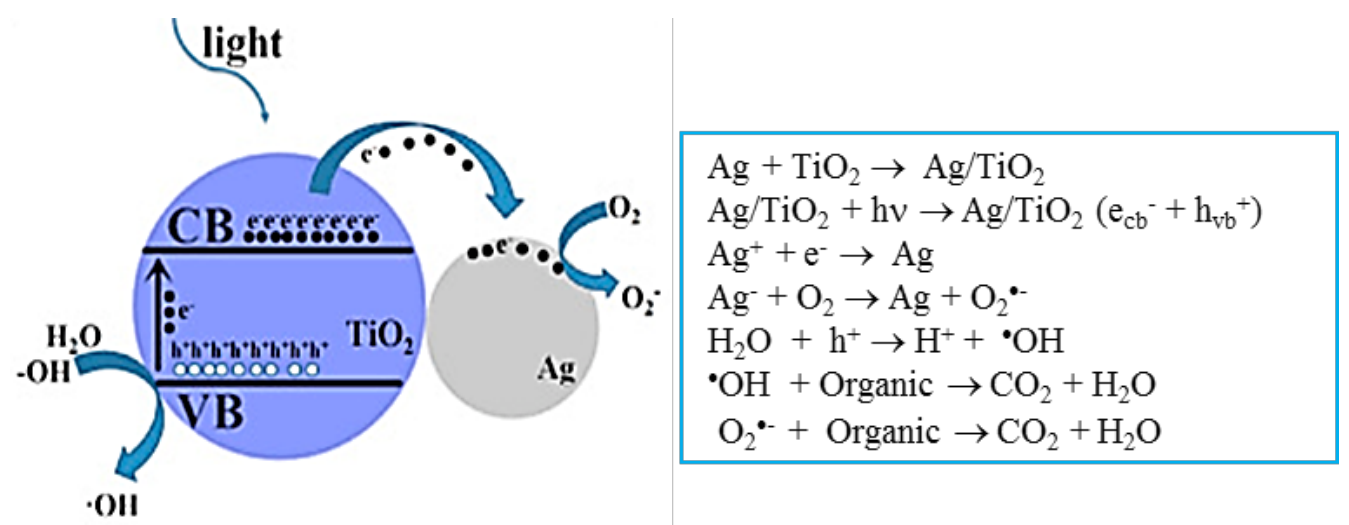

Fig. 1. Schematic diagram of the charge separation and transfer of $\mathrm{Ag}-\mathrm{TiO}_{2}$ structure [11].

The previous studies have been focused on the photocatalytic properties and the antibacterial ability of $\mathrm{Ag}-\mathrm{TiO}_{2}$ structures. Prakash Swarnakar et al. reported that silver-coated $\mathrm{TiO}_{2}$ films could enhance $\mathrm{MO}$ degradation in sunlight and increase the rate $18 \%$ over the $\mathrm{TiO}_{2}$ films under natural light. They indicated that the adsorption of $\mathrm{Ag}^{+}$significantly reduced the $\mathrm{TiO}_{2}$ band gap in the visible region thus leading to the enhanced photocatalytic properties [12]. Ramacharyulu et al. also reported that $\mathrm{Ag}-\mathrm{TiO}_{2}$ film enhanced the rate of photocatalytic degradation of $\mathrm{MB}$ when compared to $\mathrm{TiO}_{2}$ film due to the trapping the charge carriers of silver nanoparticles [13]. Selim Demirci et al. observed that $\mathrm{Ag}$-doped $\mathrm{TiO}_{2}$ films had better photocatalytic activity than un-doped $\mathrm{TiO}_{2}$ film and $0.7 \%$ was an optimal dopant concentration exhibiting maximum photocatalytic activity. These results were explained by space charge creation and the rate of charge carrier recombination due to the presence of metallic $\mathrm{Ag}$ on $\mathrm{TiO}_{2}$, narrowing the band gap of the $\mathrm{TiO}_{2}$ film [14]. Sornsanit K. et al. reported the Ag-TiO 2 composited films showed good optical 
and high antibacterial activity at eliminating the $E$. coli bacteria after 20 minutes under UV irradiation [15]. Gupta et al. studied the antibacterial activity of $\mathrm{TiO}_{2}$ and $\mathrm{TiO}_{2}$ doped $\mathrm{Ag}$ nanoparticles on various strains (staphylococcus aureus, pseudomonas aeruginosin, and escherichia coli) under visible light irradiation [16]. Their studies indicated that the enhanced bactericidal activity in the dark and under UV illumination is due to the synergistic antibacterial effect of the photocatalytic reaction of the $\mathrm{TiO}_{2}$ and the appearance of $\mathrm{Ag}$ nanoparticles on the surface. Which shows that $\mathrm{TiO}_{2}$ surface modified with $\mathrm{Ag}$ is a research direction attracted a lot of interest because of improving the photocatalytic property and antibacterial ability of the material.

In this work, the $\mathrm{TiO}_{2}$ thin film is fabricated by the $\mathrm{DC}$ magnetron sputtering method and surface modified Ag nanoparticles by the photo-reduction method. The morphology, crystalline phase and absorbance spectroscopy of the $\mathrm{Ag}-\mathrm{TiO}_{2}$ thin film are investigated by various characterization techniques (SEM, XRD, UV-Vis). In addition, the photocatalytic activity of the $\mathrm{Ag}-\mathrm{TiO}_{2}$ thin film is also evaluated using the degradation of methylene blue (MB) aqueous solution at $\lambda=664.6 \mathrm{~nm}$ under various irradiation conditions. The antibacterial experiment was conducted on the $E$. coli bacteria by bacterial counting method.

\section{MATERIALS AND METHODS}

\section{II.1. Materials}

Materials used for the synthesis of pure $\mathrm{TiO}_{2}$ thin film and $\mathrm{Ag}-\mathrm{TiO}_{2}$ thin film were Ti target (99.9\%), silver nitrate $\left(\mathrm{AgNO}_{3}\right.$ EMSURE, Merck, Germany), distilled water and methylene blue (MB, Merck, Germany).

\section{II.2. Synthesis of $\mathrm{Ag}-\mathrm{TiO}_{2}$}

The $\mathrm{TiO}_{2}$ thin film is fabricated on soda-lime glass (Marienfeld, Germany 900) by DC magnetron sputtering method. The soda-lime glass was cleaned with acetone, alcohol, and then surface treated by plasma discharge in $4.22 \times 10^{-3}$ torr vacuum before thin film deposition. A plate with $7.6 \mathrm{~cm}$ in diameter made from the pure $(99.9 \%)$ Ti was used for the target. Before sputtering, the Ti target was pre-sputtered for about 5 minutes with a shutter covering the substrate. $\mathrm{TiO}_{2}$ thin film was deposited at the power of $100 \mathrm{~W}$ in $240 \mathrm{~min}$, and the argon-oxygen flow rate ratio of $\mathrm{Ar}: \mathrm{O}_{2}=6: 20$. The $\mathrm{TiO}_{2}$ thin film was modified with $\mathrm{Ag}$ nanoparticles by the photo-reduction method and conducted according to the diagram in Fig. 2.

\section{II.3. Characterization methods}

The crystal structure, morphology, and absorbance spectroscopy of $\mathrm{Ag}-\mathrm{TiO}_{2}$ thin film are characterized by X-ray diffraction (Bruker D8-ADVANCE), scanning electron microscope (SEM, FE-SEM Hitachi S-4800, and UV-Vis spectrophotometer (JASCO - V670), respectively. These measurements conducted at Nanotechnology Lab, SHTP labs.

The photo-catalytic activities of $\mathrm{Ag}-\mathrm{TiO}_{2}$ thin film are evaluated by the photo-degradation of methylene blue (MB) under different irradiation conditions: UV (Reptile UVB100-PT 2187, 25W), visible light (Compact Lamp-Philips, 25W). UV-Vis spectrophotometer (UV-2450; Shimadzu, Tokyo-Japan) is then used for monitoring the absorption of MB aqueous solution at a wavelength of $664.6 \mathrm{~nm}$. The photocatalytic evaluation process performed at the Department of Applied Physics, Faculty of Physics \& Engineering Physics, University of Science - VNUHCM. The antibacterial activity test is performed against $E$. coli (gram-negative and gram-positive) with 


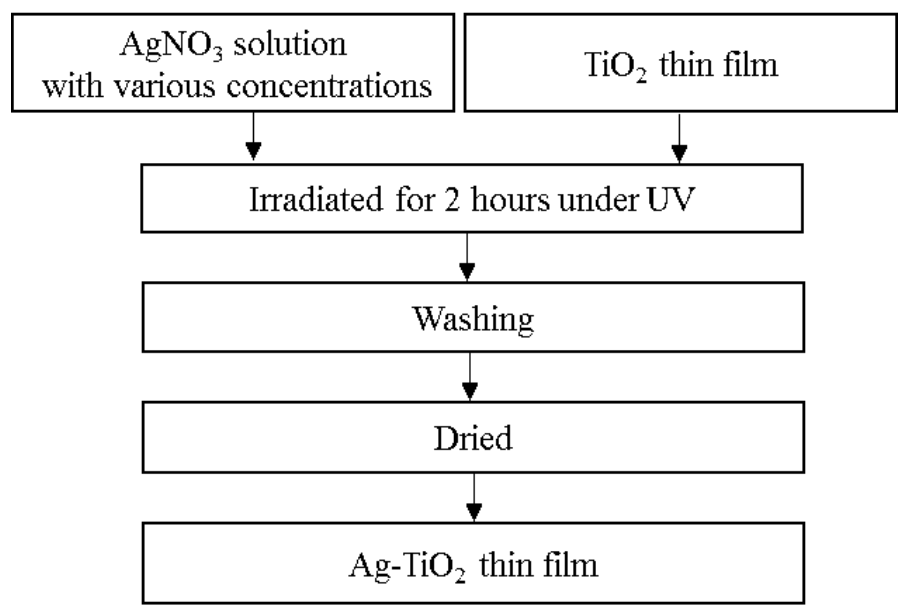

Fig. 2. The fabrication process of the $\mathrm{Ag}-\mathrm{TiO}_{2}$ thin film.

the initial bacterial cell concentration is about $1 \times 10^{5} \mathrm{CFU} / \mathrm{mL}$. The inactivation of $E$. coli on the $\mathrm{Ag}-\mathrm{TiO}_{2}$ thin film is compared with the pure $\mathrm{TiO}_{2}$ thin film. To quantitatively evaluate the antibacterial activity of samples, $20 \mu \mathrm{L}$ of $E$. coli is added to each sample with the approximate surface area of $1 \mathrm{~cm}^{2}$. The surfaces with bacterial suspension are illuminated with UV-light and visible light in 60 and 120 minutes. Then $50 \mu \mathrm{L}$ of the resultant bacterial suspension and its $10^{3}$-fold dilutions are spread onto the nutrient agar plates. The number of surviving luminescent bacterial colonies (colony forming unit, CFU) is counted after incubation at $37{ }^{\circ} \mathrm{C}$ for 24 hours. Then, they are counted by manual counting method, it means that the primary trick in colony-counting is to count each colony dot on the surface of petri dish. To easily and correctly count colonies, we conduct to place the grid over the plate. Generally, we have to count at least 3 times, and only use plates containing smaller than 300 colonies to count to make correctly the number of colonies, then average them to get an average of living number of living colonies accurately. The disinfection efficiency $(\mathrm{D} \%)$ is calculated by the following formula:

$$
D(\%)=\frac{C_{\text {control }}-C_{\text {photocalytic.material }}}{C_{\text {control }}} \times 100,
$$

where, $C_{\text {control }}$ is the number of surviving bacteria in the control dish, $C_{\text {photocatalytic.material }}$ is the number of living bacteria of each disk containing photocatalytic material.

This experiment is conducted at Biochemical Lab, Faculty of Biology \& Biotechnology, University of Science - VNUHCM.

\section{RESULTS AND DISCUSSION}

\section{III.1. The morphological and crystal structure characteristics of pure $\mathrm{TiO}_{2}$ thin film and $\mathrm{Ag}-\mathrm{TiO}_{2}$ thin film}

Figure 3 shows the surface morphology and the transmittance of the $\mathrm{TiO}_{2}$ thin film. The surface of pure $\mathrm{TiO}_{2}$ thin film shows the film roughness with $290 \mathrm{~nm}$ film thickness (Fig. 3a), the transmittance is about $85 \%$ (Fig. 3b). Calculating the porosity of the $\mathrm{TiO}_{2}$ thin film based on 
the expression of Clausius Mosstti indicates that its porosity is 0.80 , and fits with the model of Thornton [17].
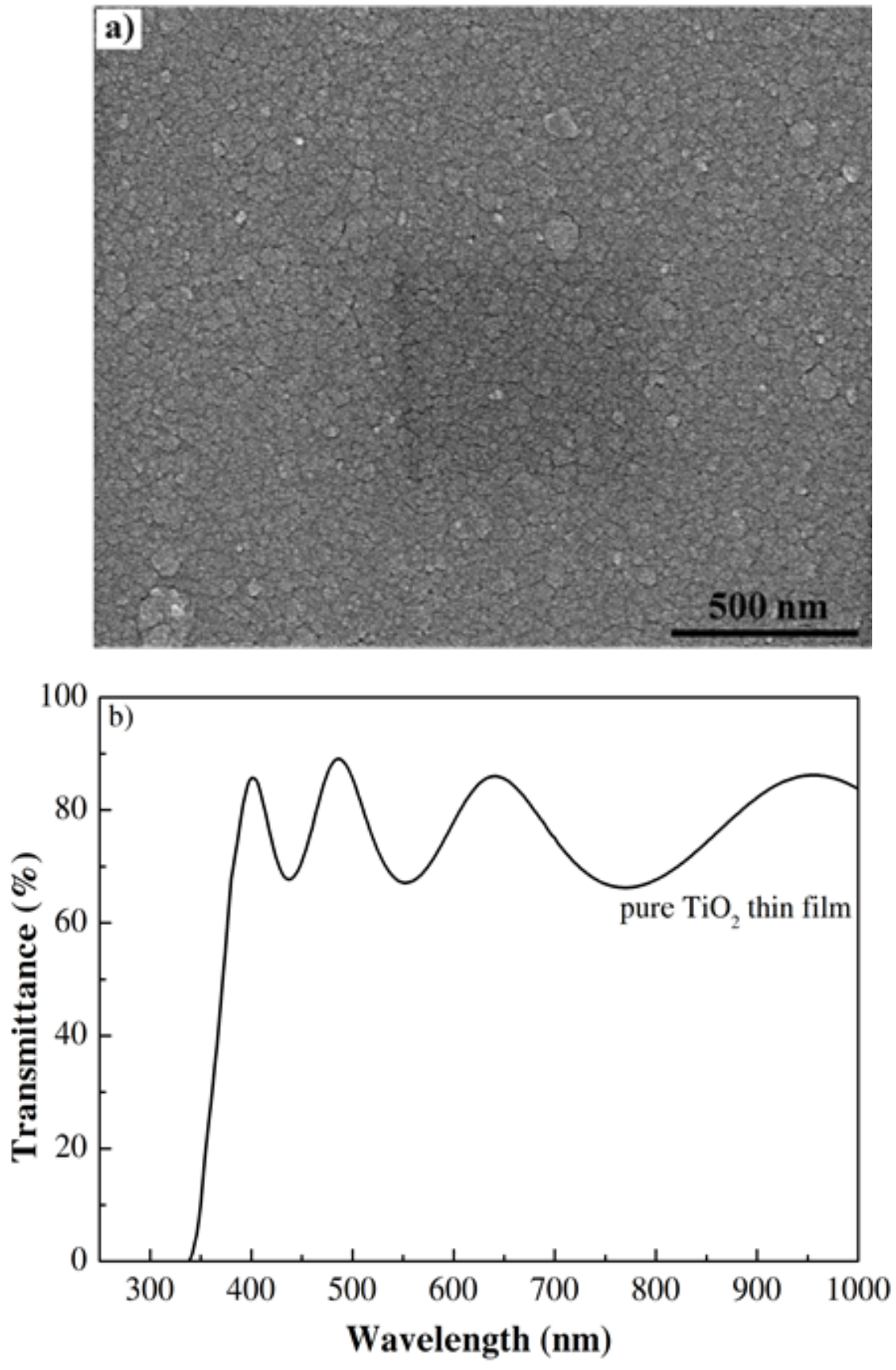

Fig. 3. The SEM images (a) and the transmittance pattern (b) of pure $\mathrm{TiO}_{2}$ thin film. 
$\mathrm{TiO}_{2}$ surfaces modified with noble Ag nanoparticles via a photo-reduction method with the parameters preparation are presented in Table 1.

Table 1. The fabrication conditions of $\mathrm{Ag}-\mathrm{TiO}_{2}$ thin film with different $\mathrm{AgNO}_{3}: \mathrm{TiO}_{2}$ ratio.

\section{Samples $\quad \mathrm{AgNO}_{3}: \mathrm{TiO}_{2}(\mathrm{wt})$ The modification time (hours)}

\begin{tabular}{lll}
\hline \hline Pure $\mathrm{TiO}_{2}$ & $0.0: 100$ & 2 \\
\hline $\mathrm{Ag}-\mathrm{TiO}_{2}-0.5$ & $0.5: 100$ & 2 \\
\hline $\mathrm{Ag}-\mathrm{TiO}_{2}-1.0$ & $1.0: 100$ & 2 \\
\hline $\mathrm{Ag}-\mathrm{TiO}_{2}-1.5$ & $1.5: 100$ & 2 \\
\hline $\mathrm{Ag}-\mathrm{TiO}_{2}-2.5$ & $2.5: 100$ & 2 \\
\hline
\end{tabular}

Figure 4 shows $\mathrm{XRD}$ patterns of pure $\mathrm{TiO}_{2}$ and $\mathrm{Ag}-\mathrm{TiO}_{2}-1.0$ thin films. The diffraction peak appears at $2 \theta=25.08^{\circ}$ corresponding to $\mathrm{A}(101)$ peak along (001) crytal direction of $\mathrm{TiO}_{2}$ anatase with the highest intensity and Ag peaks looking unclearly compare to others in this XRD result. However, the appearence of $\mathrm{Ag}$ in $\mathrm{TiO}_{2}$ thin film leads to decrease their crystallinity or intensity of (101) peak.

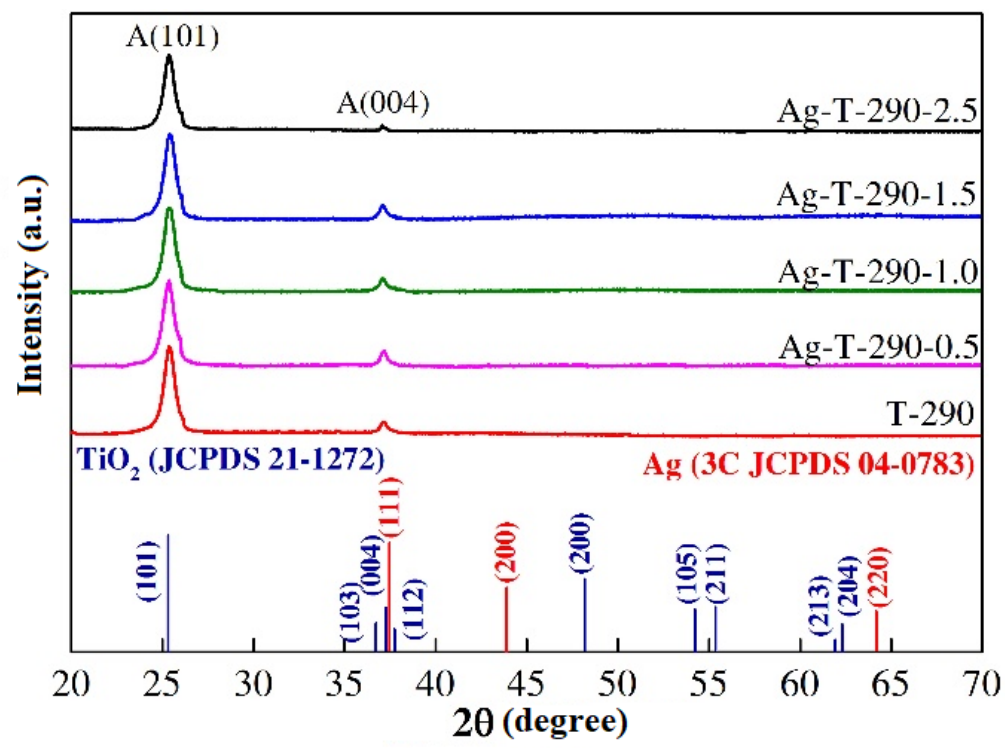

Fig. 4. XRD pattern of pure $\mathrm{TiO}_{2}$ film and $\mathrm{Ag}-\mathrm{TiO}_{2}$ with different $\mathrm{AgNO}_{3}: \mathrm{TiO}_{2}$ ratio. 
The UV-vis absorption spectra of the pure $\mathrm{TiO}_{2}$, and $\mathrm{Ag}-\mathrm{TiO}_{2}$ with different $\mathrm{AgNO}_{3}: \mathrm{TiO}_{2}$ ratio is displayed in Fig. 5. Compared with the pure $\mathrm{TiO}_{2}$ thin film, the absorption spectrum of $\mathrm{Ag}-$ $\mathrm{TiO}_{2}$ samples show a single broad at the range of $380 \div 430 \mathrm{~nm}$, attributing to the charge-transfer from the valence band to the conduction band (Fig. 5). The optical bandgap energy $\left(E_{g}\right)$ of pure $\mathrm{TiO}_{2}$ and $\mathrm{Ag}-\mathrm{TiO}_{2}$ are estimated by Kubelka-Munk equation $\left(E_{g}=1240 . \lambda^{-1}\right)$. The results show that the $E_{g}$ of $\mathrm{Ag}-\mathrm{TiO}_{2}$ samples ranged in $3.15 \div 3.2 \mathrm{eV}$ and narrower than that of pure $\mathrm{TiO}_{2}$ thin film, which indicate that the surface modification has expanded the absorption wavelength region of the pure $\mathrm{TiO}_{2}$ because of the surface plasmon resonance of noble metals on the surface of $\mathrm{TiO}_{2}[18]$.

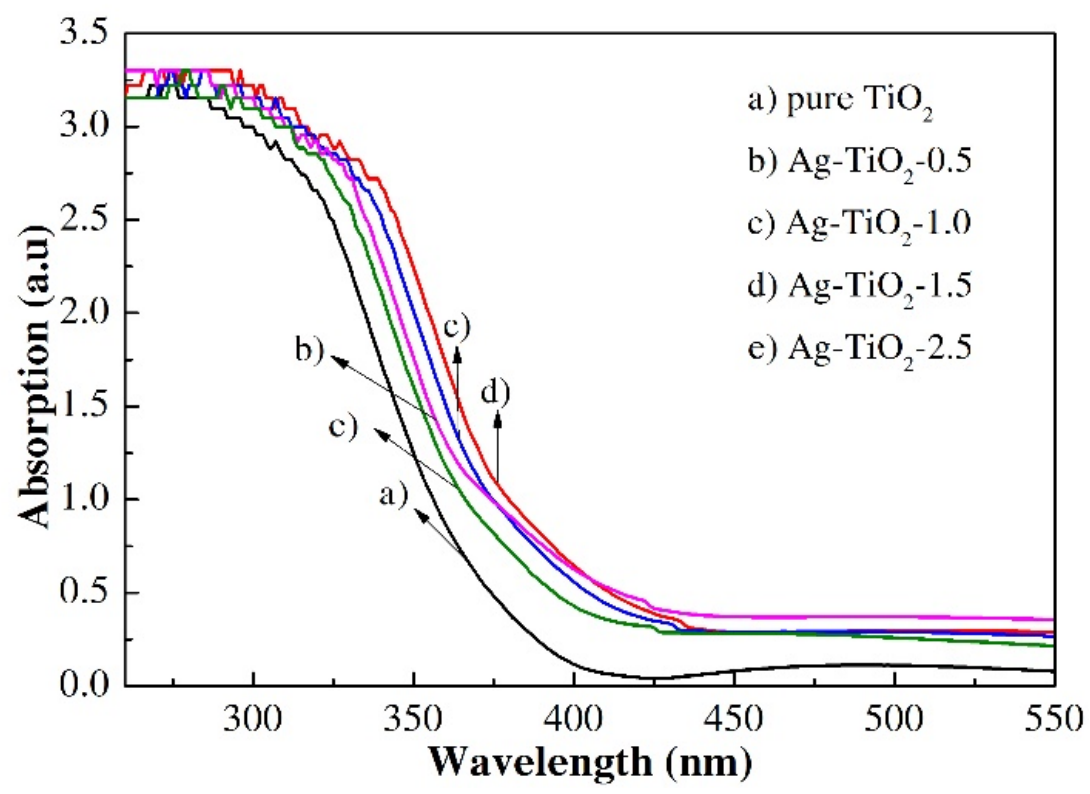

Fig. 5. UV-vis absorption spectra of (a) pure $\mathrm{TiO}_{2}$ and $\mathrm{Ag}-\mathrm{TiO}_{2}$ with different $\mathrm{AgNO}_{3}$ : $\mathrm{TiO}_{2}$ ratio and (b) plots of $[\alpha \mathrm{h} v]^{1 / 2}$ versus photon energy (hv) for samples given in (a).

\section{III.2. Photocatalytic activity and antibacterial ability of pure $\mathrm{TiO}_{2}$ thin film and $\mathrm{Ag}-\mathrm{TiO}_{2}$ thin film}

The photocatalytic ability of pure $\mathrm{TiO}_{2}$ thin film and $\mathrm{Ag}-\mathrm{TiO}_{2}$ samples are evaluated by the degradation of MB in the presence of samples under the UV light and visible light (Fig. 6). The result shows that the degradation efficiency of $\mathrm{MB}$ solution of the pure $\mathrm{TiO}_{2}$ thin film, $\mathrm{Ag}-$ $\mathrm{TiO}_{2}-0.5, \mathrm{Ag}-\mathrm{TiO}_{2}-1.0, \mathrm{Ag}-\mathrm{TiO}_{2}-1.5$, and $\mathrm{Ag}-\mathrm{TiO}_{2}-2.5$ under $\mathrm{UV}$ light are in turn about $76 \%$, $91 \%, 87 \%, 84 \%$, and $82 \%$ within 90 min, respectively (Fig. 6a). This indicates that the UV light photocatalytic activity of the $\mathrm{Ag}-\mathrm{TiO}_{2}$ thin film exhibits a higher photodegradation rate than pure $\mathrm{TiO}_{2}$ thin film samples. These results may be explained by following reasons:

i) The enhanced photodegradation rate by $\mathrm{TiO}_{2}$ pure was attributed to by the reactive oxygen species (ROSs). While, $\mathrm{TiO}_{2}$ has been known as an UV absorbance material. So, when the $\mathrm{TiO}_{2}$ and $\mathrm{Ag}-\mathrm{TiO}_{2}$ samples are irradiated under a suitable wavelengh, the electron-hole pairs are 
generated as indicated in Eq. (1). Then, they can react immediately with dye molecules (Eq. (2)) or with water and dissolved oxygen to produce free radical species and ROSs, such as $\mathrm{OH}, \mathrm{O}_{2-}, \mathrm{HO}_{2}$ and $\mathrm{H}_{2} \mathrm{O}$. They may produce oxidative stress and perform oxidation-reduction reactions leading to enhance dye molecules degradation (Eq. (3)). These above discussions are shown the following equations:

$$
\begin{aligned}
& \mathrm{Ag} / \mathrm{TiO}_{2}+h v \rightarrow \mathrm{Ag} / \mathrm{TiO}_{2}+e^{-}+h^{+} \text {(electron-hole photogeneration) } \\
& h^{+}+\text {dye } \rightarrow \text { degraded compounds } \\
& e^{-}+\mathrm{O}_{2} \rightarrow{ }^{\bullet} \mathrm{O}_{2}^{-} \\
& h^{+}+\mathrm{H}_{2} \mathrm{O} \rightarrow \mathrm{OH}+\mathrm{H}^{+} \\
& e^{-}+\mathrm{O}_{2} \rightarrow \mathrm{O}_{2}^{-} \\
& \mathrm{O}_{2}^{-}+\mathrm{H}^{+} \rightarrow \mathrm{HO}_{2} \\
& \mathrm{O}_{2}^{-}+2 \mathrm{H}_{2} \mathrm{O} \rightarrow 3 \mathrm{OH}+{ }^{-} \mathrm{OH} \\
& \mathrm{O}_{2}^{-}+\mathrm{HO}_{2}+\mathrm{H}^{+} \rightarrow \mathrm{H}_{2} \mathrm{O}_{2}+\mathrm{O}_{2} \\
& \mathrm{H}_{2} \mathrm{O}_{2}+e^{-}+\mathrm{OH} \rightarrow{ }^{-} \mathrm{OH} \\
& \mathrm{MB}+\left\{\mathrm{OH}, \mathrm{O}_{2}, \mathrm{HO}_{2} \text { or }^{-} \mathrm{OH}\right\} \rightarrow \text { original products }
\end{aligned}
$$

ii) The large specific surface area can enhance the UV light absorption leading to improve electron-hole photogeneration and improve photocatalytic efficiency. Whereas, the Ag contents were too much, it is possible that they would cover the $\mathrm{TiO}_{2}$ surface and prevent light absorption, lead to decrease in photocatalytic efficiency. Additionally, the Schottky barrier formation established by the metal-semiconductor interaction. This plays a vital role in separating and inhibiting the rapid recombination of photogenerated electron-hole pairs. It is almost certain that the efficiency of photocatalytic activity can be significantly enhanced.

Under visible light, the degradation efficiency of $\mathrm{MB}$ solutions in $\mathrm{Ag}-\mathrm{TiO}_{2}-1.0$ is $96 \%$ while $\mathrm{Ag}-\mathrm{TiO}_{2}-0.5, \mathrm{Ag}-\mathrm{TiO}_{2}-1.5$, and $\mathrm{Ag}-\mathrm{TiO}_{2}-2.5$ turns in about $94 \%, 89 \%$, and $84 \%$ (Fig. 6b). This means that the $\mathrm{Ag}-\mathrm{TiO}_{2}$ thin film samples show a higher photodegradation rate than the pure $\mathrm{TiO}_{2}$ thin film in the visible irradiation, and the $\mathrm{Ag}-\mathrm{TiO}_{2}-1.0$ thin film exhibits the best degradation efficiency of $\mathrm{MB}$ dye under the visible light. It may be explained by $\mathrm{Ag}$ deposition on the $\mathrm{TiO}_{2}$ surface can act as electron-hole separation centers [19], and increase the rate of the electron-transfer process. According to the schematic diagram for the charge separation and transfer in Fig. 1, the electron transfer from the $\mathrm{TiO}_{2}$ conduction band to metallic silver particles at the interface is thermodynamically possible because the Fermi level of $\mathrm{TiO}_{2}$ is higher than that of silver metals [11]. This result in the formation of Schottky barrier at metal-semiconductor contact region, which limited the charge combination and enhanced the photocatalytic activity of the $\mathrm{Ag}-\mathrm{TiO}_{2}$ thin film. In addition, it has reported that the surface plasmon resonance (SPR) of noble metal and $\mathrm{TiO}_{2}$ is excited by visible light, enhancing the surface electron excitation and electron-hole pairs separation [19]. All these leaded the $\mathrm{Ag}-\mathrm{TiO}_{2}$ thin film photocatalytic performance significantly improved. However, some previous studies reported that at the Ag contents above its optimum, the Ag particles could also act as recombination centers, which reduced the photocatalytic performance [20], and thus Ag content played a significant role in enhancing the photocatalytic activity of $\mathrm{TiO}_{2}$. 


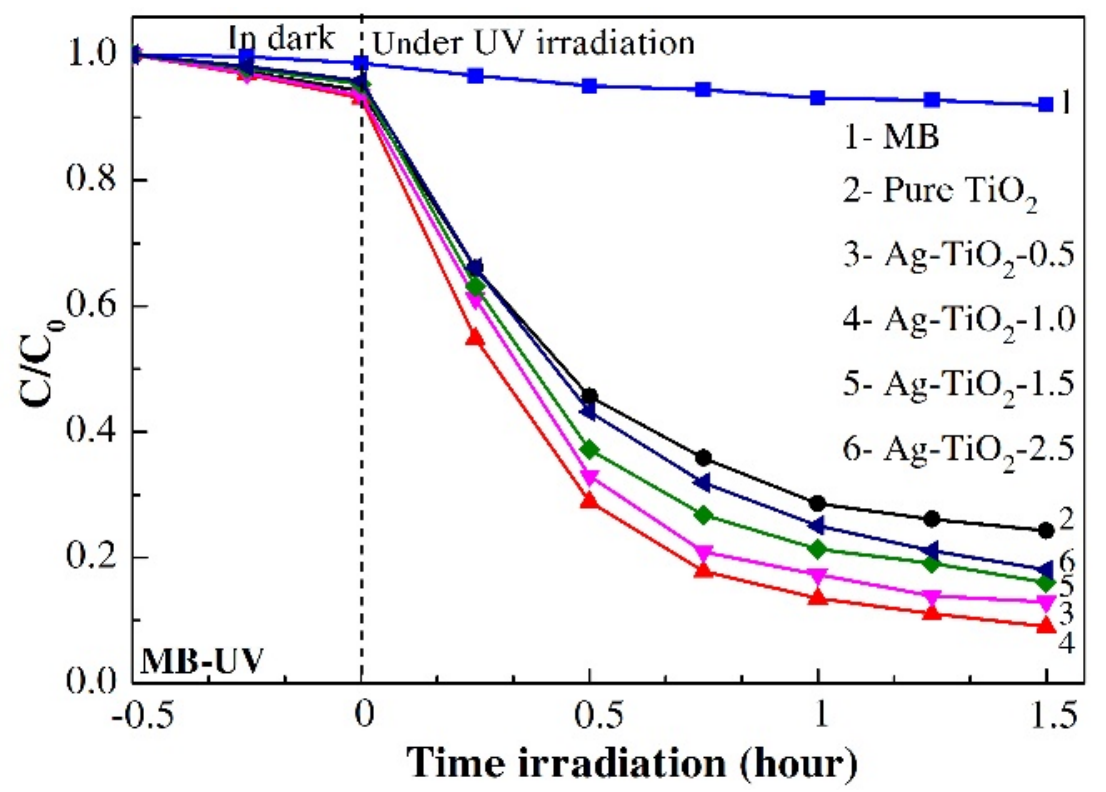

(a)

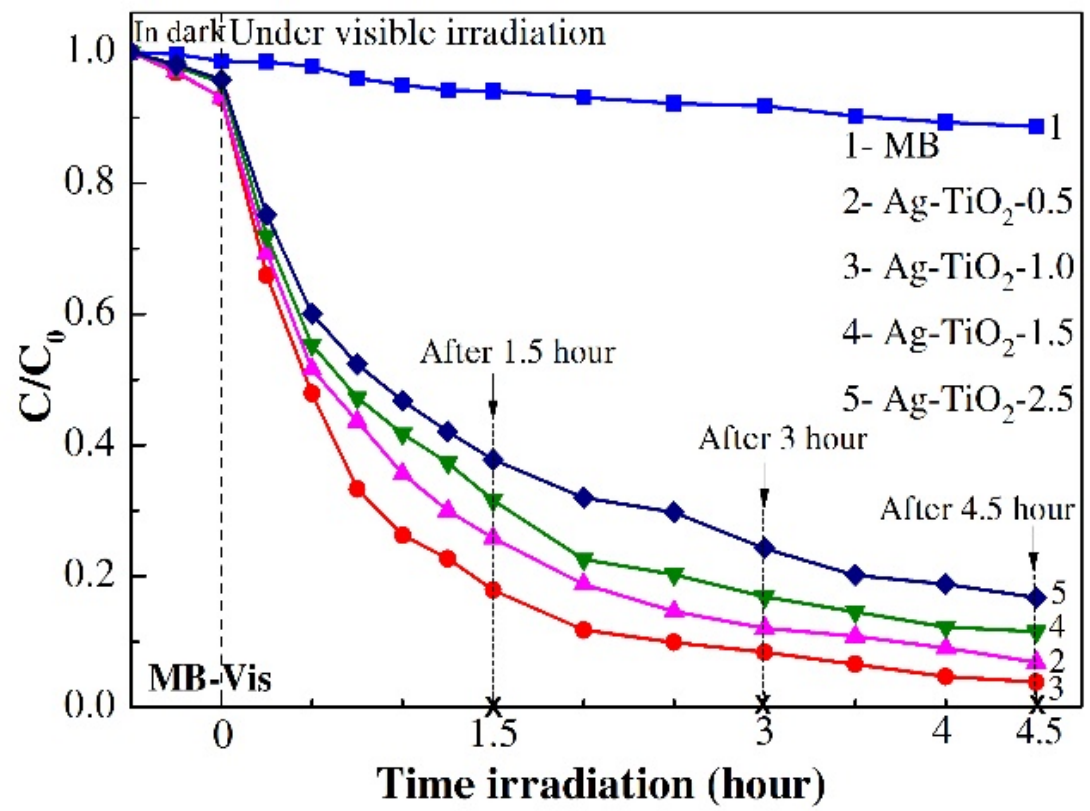

(b)

Fig. 6. Photocatalytic degradation of the aqueous MB under (a) UV irradiation, (b) visible irradiation with pure $\mathrm{TiO}_{2}$ and $\mathrm{Ag}-\mathrm{TiO}_{2}$ samples.

Figure 7 (1) shows the antibacterial efficiency of the pure $\mathrm{TiO}_{2}$ and $\mathrm{Ag}-\mathrm{TiO}_{2}$ thin films tested in UV irradiation for $60 \mathrm{~min}$. It can be clearly seen that the pure $\mathrm{TiO}_{2}$ thin film and $\mathrm{Ag}-$ $\mathrm{TiO}_{2}$ samples have high antibacterial effect under UV irradiation. However, the pure $\mathrm{Ag}-\mathrm{TiO}_{2}$ 
thin film that shows a higher antibacterial efficiency compared with the pure $\mathrm{TiO}_{2}$ thin film. The disinfection efficiency of the pure $\mathrm{TiO}_{2}$ thin film, $\mathrm{Ag}-\mathrm{TiO}_{2}-0.5, \mathrm{Ag}-\mathrm{TiO}_{2}-1.0, \mathrm{Ag}-\mathrm{TiO}_{2}-1.5$, and $\mathrm{Ag}-\mathrm{TiO}_{2}-2.5$ are about $72 \%, 95.1 \%, 99.3 \%, 100 \%$, and $90.3 \%$, respectively (Fig. 8). The best disinfection efficiency is 1-1.5.wt\% of Ag content. The major cellular constituents such as proteins, lipids, polysaccharides, and nucleic acids, are organic compounds which can be attacked by ROSs. So they are the typical photocatalytic disinfection process. Under UV light, the ROSs not only produced by $\mathrm{TiO}_{2}$ when UV absorpted but also by Ag nanoparticles. The generation of ROSs in bacterial cells causes cell death. The higher of ROSs generated, the higher of antibacterial efficacy.
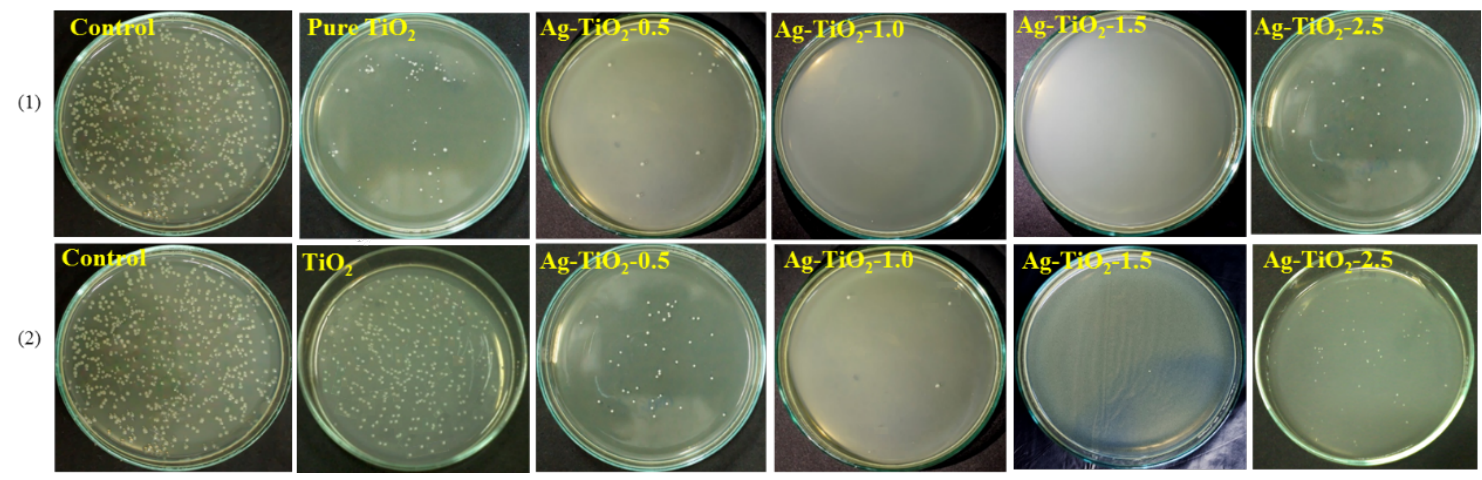

Fig. 7. Photographs of E.coli bacteria grown on agar plate treated with: (1) Under UV irradiation for $60 \mathrm{~min}$; (2) Under visible irradiation for $120 \mathrm{~min}$.

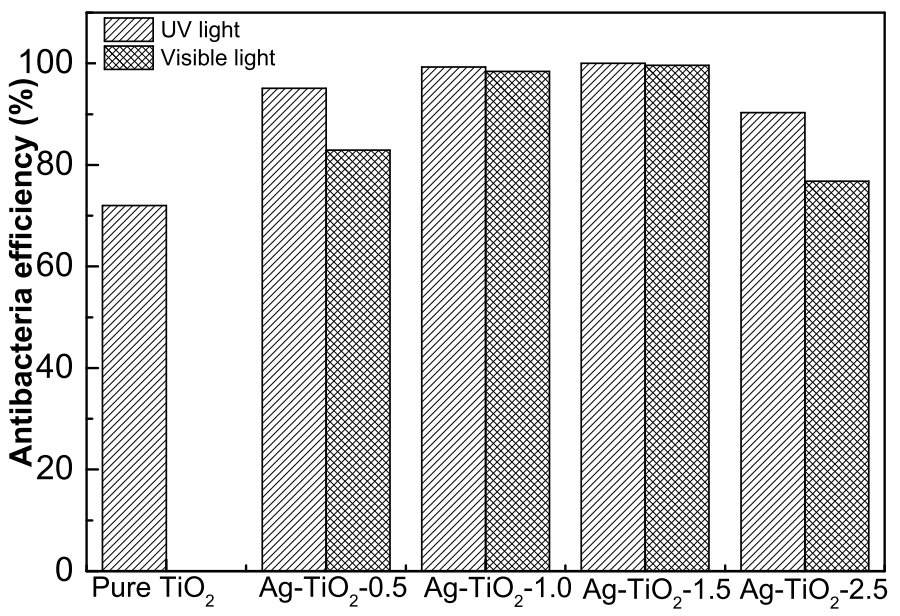

Fig. 8. The antibacterial efficiency of E. coli in the liquid film on pure $\mathrm{TiO}_{2}$ thin film, $\mathrm{Ag}-\mathrm{TiO}_{2}$ thin film with the various concentration of $\mathrm{Ag}$ under 60 minutes of $\mathrm{UV}$ and 120 minutes of visible irradiation.

The antibacterial efficiency of the pure $\mathrm{TiO}_{2}$ and $\mathrm{Ag}-\mathrm{TiO}_{2}$ thin films test in the visible irradiation for $120 \mathrm{~min}$ is showed in Fig. 7 (2). The result indicates that the Ag deposited on 
the $\mathrm{TiO}_{2}$ thin film surface have the higher disinfection efficiency than pure $\mathrm{TiO}_{2}$ thin film and the visible light antibacterial performance of $\mathrm{Ag}-\mathrm{TiO}_{2}$ thin film increases with an increasing in $\mathrm{Ag}$ concentration from $2.5 \div 10 \%$. It shows clearly that the inhibition efficiency of $\mathrm{Ag}-\mathrm{TiO}_{2}-$ 1.5 is $99.6 \%$ while $\mathrm{Ag}-\mathrm{TiO}_{2}-0.5, \mathrm{Ag}-\mathrm{TiO}_{2}-1.0$, and $\mathrm{Ag}-\mathrm{TiO}_{2}-2.5$ thin film are about $82.9 \%$, $98.4 \%$, and $76.8 \%$, respectively (Figure 8). The best disinfection efficiency is $1-1.5$.wt $\%$ of $\mathrm{Ag}$ content. Those results may be explained by following reasons: i) the antibacterial activity of $\mathrm{Ag}$ nanoparticles is due to their ability of producing ROSs; ii) the formation of Schottky barrier between $\mathrm{Ag}-\mathrm{TiO}_{2}$ prevent the electron-hole pairs recombine rapidly, and the amount of reactive oxygen species (ROSs) is increased Thus, $\mathrm{Ag}$ deposition on $\mathrm{TiO}_{2}$ thin film displays significant antibacterial effect in the visible light environment.

\section{CONCLUSIONS}

In this work, the pure $\mathrm{TiO}_{2}$ and $\mathrm{Ag}-\mathrm{TiO}_{2}$ thin film are fabricated by the $\mathrm{DC}$ magnetron sputtering method and photo-reduction process. The results show that $\mathrm{Ag}$ deposition on $\mathrm{TiO}_{2}$ thin film surface effects the crystal structure, and the absorption of the $\mathrm{Ag}-\mathrm{TiO}_{2}$ thin film would be enhanced in the visible light region. The $\mathrm{TiO}_{2}$ thin film was modified with Ag nanoparticles with a various Ag content showed an increase in the MB photodegradation under UV and visible irradiation as compared to the pure $\mathrm{TiO}_{2}$ thin film. The inactivation of E. coli under UV and visible irradiation of pure $\mathrm{TiO}_{2}$, and $\mathrm{Ag}-\mathrm{TiO}_{2}$ thin film with different $\mathrm{Ag}$ concentration are compared. It is found that the photocatalytic property and antibacterial ability of $\mathrm{Ag}-\mathrm{TiO}_{2}$ thin film depend on $\mathrm{Ag}$ content and irradiation condition, in which, $\mathrm{Ag}-\mathrm{TiO}_{2}-1.5$ sample exhibited the best antibacterial efficiency under UV and visible irradiation.

\section{ACKNOWLEDGMENT}

We gratefully thank Ho Chi Minh Department of Science and Technology support for this project with number 147/2016/HĐ-SKHCN.

\section{REFERENCES}

[1] T. Bora and J. Dutta, Journal of nanoscience and nanotechnology 14 (2014) 613.

[2] V. Puddu, H. Choi, D. D. Dionysiou and G. L. Puma, Appl. Catal., B 94 (2010) 211.

[3] J. Ding, Preparation of tio2 photocatalysis antibacterial ceramics, Key Engineering Materials, vol. 575, Trans Tech Publ, 2014, pp. 302-305.

[4] C. Garlisi, G. Scandura, A. Alabi, O. Aderemi and G. Palmisano, J. Adv. Chem. Eng. 5 (2015) e103.

[5] J. Zhu and M. Zäch, Curr. Opin. Colloid Interface Sci. 14 (2009) 260.

[6] M. Gholami, M. Shirzad-Siboni, M. Farzadkia and J.-K. Yang, Desalin. Water Treat. 57 (2016) 13632.

[7] X. Yuan, W. Xu, F. Huang, D. Chen and Q. Wei, Surf. Eng. 33 (2017) 231.

[8] V. Vaiano, O. Sacco, D. Sannino, P. Ciambelli, S. Longo, V. Venditto and G. Guerra, J. Chem. Technol. Biotechnol. 89 (2014) 1175.

[9] R. S. Varma, N. Thorat, R. Fernandes, D. Kothari, N. Patel and A. Miotello, Catal. Sci. Technol. 6 (2016) 8428.

[10] K. Ubonchonlakate, L. Sikong and F. Saito, Procedia Engineering 32 (2012) 656.

[11] T. Wang, J. Wei, H. Shi, M. Zhou, Y. Zhang, Q. Chen and Z. Zhang, Physica E Low Dimens. Syst. Nanostruct. 86 (2017) 103.

[12] P. Swarnakar, S. R. Kanel, D. Nepal, Y. Jiang, H. Jia, L. Kerr, M. N. Goltz, J. Levy and J. Rakovan, Solar Energy 88 (2013) 242.

[13] P. Ramacharyulu, G. Prasad, A. Srivastava et al., RSC Advances 5 (2015) 1309. 
244 FABRICATION AND EVALUATION OF THE PHOTOCATALYTIC, ANTIBACTERIAL ACTIVITY OF Ag-TiO ${ }_{2} \ldots$

[14] S. Demirci, T. Dikici, M. Yurddaskal, S. Gultekin, M. Toparli and E. Celik, Appl. Surf. Sci. 390 (2016) 591.

[15] K. Sornsanit, M. Horprathum, C. Chananonnawathorn, P. Eiamchai, S. Limwichean, K. Aiempanakit and J. Kaewkhao, Fabrication and characterization of antibacterial ag-tio2 thin films prepared by dc magnetron cosputtering technique, Adv. Mat. Res., vol. 770, Trans Tech Publ, 2013, pp. 221-224.

[16] K. Gupta, R. Singh, A. Pandey and A. Pandey, Beilstein J. Nanotechnol. 4 (2013) 345.

[17] J. A. Thornton, J. Vac. Sci. Technol. 11 (1974) 666.

[18] X. Zhou, G. Liu, J. Yu and W. Fan, J. Mater. Chem. 22 (2012) 21337.

[19] B. Xin, Z. Ren, H. Hu, X. Zhang, C. Dong, K. Shi, L. Jing and H. Fu, Appl. Surf. Sci. 252 (2005) 2050.

[20] M. Harikishore, M. Sandhyarani, K. Venkateswarlu, T. Nellaippan and N. Rameshbabu, Procedia Materials Science 6 (2014) 557. 